\title{
The Impact of Women's Political Empowerment Policy: A Perspective from the Idukki District of Kerala
}

\author{
Titty Varghese \\ Kaunas University of Technology \\ A. Mickevičiaus 37, LT-44244 Kaunas \\ cross' $^{\text {ref }}$ http://dx.doi.org/10.5755/j01.ppaa.18.3.24710
}

\begin{abstract}
Women's exposure to political power and their influence on policies has expanded tremendously in recent decades. However, females are nowhere proportional to males in their impact and practice of political legitimacy, although political empowerment research on women's role is continuing. The Indian government national program of 'Panchayati Raj Institutions' act of 1992 was an outstanding policy mechanism for increasing women's political participation at the national level. This act provides 50 $\%$ reservation seats for women in the Local Self Government, and thus women were capable of attaining power in the political realm. Through this policy, there is a greater possibility for women to elected in the political realms and thus process a higher role in welfare mechanisms in their respective administrative locality than before. In this context, this article aims to explore the importance of the Panchayati Raj Institution policy on the political empowerment of women in the panchayat. To find out the impact of policy, this paper conducted an empirical study by collecting the primary data from elected women representatives in one district of Kerala. The results could assess the significance of increasing women's political empowerment and their position in Kerala society.
\end{abstract}

Keywords: women's political empowerment, Panchayati Raj Institutions, local self-government, Kerala

Raktažodžiai: moteru emancipacija, moteru politinès teisés, vietovès lygmens institucijos, savivalda, Kerala

\section{Introduction}

Gender discrimination and its associated socio-cultural and economic segregation significantly affect the overall development of society. Gender discrimination is the most common form of discrimination against women in the community. In this twenty-first century, we can see that women were excluded from the field of politics for various reasons. In many corners of the world, the male domination overpower is visible. India is the world's largest democratic nation. Women and children make up nearly half of India's total population as per the 2011 census (Central Statistics Office, Government of India, 2018). Therefore, more women's participation is essential in a developing country like India in the realm of politics and governance. Nevertheless, there are many barriers to women's participation in the political arena in the social context of the country. One of the important gender discriminations affecting Indian society is the disparities and inequalities in the workforce where necessary modifications need to introduce to overcome this scenario. It can facilitate the assistance of human resource development staff and other policy mechanisms at the governmental level that can enhance the situation, thereby decreasing the gender gap.

Nonetheless, it requires constant attempts from the policy level to decrease the concept of gender inequality, which deeply embedded in the Indian social fabric, including household relationships and societal relationships. The concept of male domination and women's subordination, which been socially constructed over the millennia, has resulted in this situation. Given the progress of different fields such as health, living standards and access to basic needs, it is evident that the gender domain has not been distributed (Batra \& Reio, 2016). Political empowerment of women can be interpreted as a factor, which increases their capacity to access 
resources and skills and success in shaping and enforcing gender equality policies along with active involvement in decision-making. The political emancipation of women was facing challenges such as traditional norms created by men in society (Pratchett et al., 2009). Historical evidence also indicates that women's right to property and income has always been under scrutiny because women have not enough rights, as men were entitled due to the male domination and control of societal norms. So that national, local and public service organisations have much responsibility in encouraging the empowerment of women in their social, political, and economic progress and towards the achievement of gender equality (Narayan-Parker, 2005).

Women's political empowerment involves aspects such as their involvement in accessing all sources of information on political participation, supporting political structures through voting systems, engaging in civic activities, supporting the legislative process, representing women at regional, state, and national level and the lobbying for women's rights in parliaments. Political empowerment of women, nevertheless, gets much less attention compared to other forms of empowerment, such as financial and cultural, due to the patriarchal facet of society and the inclination that political empowerment is least concerned as it did not really contribute to the vulnerable situations of women in general, as social and economic empowerment are really essential for equality. There are generally different government programs for revenue creation and associated operations because there is a concealed concept that economically stable females can be an active political participant. So many systems focus solely on women's financial or social development rather than on political empowerment (Berkovitch \& Kemp, 2010). A society without women's development in their social, economic, and political life cannot be regarded as a progressive society. Johnson (2005) states that "women's empowerment is not just an outcome, but a process". It can be accomplished after the application of multiple kinds of government policies and their effective implementation and evaluation mechanisms. In this cycle of transformation, there is a great need to include more women in the policy-making system. Female empowerment can be defined as an increased development process that could enhance the role of women in growth and cooperation within a social structure and establish precise development approaches (Kark et al., 2003). Political empowerment is a tool for capacity building that leads to increased involvement in decision-making, exercising power, and therefore more significant participation in politics. There are various studies on women empowerment, yet, there is a lack of sufficient research on the need for political empowerment of women in India especially after the implementation of Panchayati Raj Institutions (PRI) policies at the national and local level especially in the state of Kerala. The meaning of panchayat is a village council, and raj means the rule. Therefore, that Panchayati Raj means rules in a village council (Gandhi \& Prabhu, 1959). Thus, it is essential to analyses further the impact of this policy on the elected women in the panchayat level with a focus on the research question on how does PRI policy empowers women in their political leadership at the panchayat level.

The research object of this article is women's political empowerment.

The article aims to analyse women's political empowerment with the focus on the Indian constitutional amendment act of PRIs of 1992 and elected women's representative role in the Local Self Government (LSG).

This article sets the following tasks:

1. To define women's political empowerment in the Indian context and identify various duties of elected panchayat presidents;

2. To address the political empowerment of women in Kerala;

3. To access the role of PRI's policy on empowering women in the political sphere.

To find out the above-said aim, it is essential to conduct an empirical study. The article argues that due to the implementation of the PRI system women got more chances to be active actors in the political process in the LSG and thus they have more opportunity in involving the developmental process in their panchayat. The article presents the results of empirical research. The author has analysed primary sources, which are empirical study. The primary data collected by interviews from 25 elected women panchayat presidents who are in their positions from 2015 until 
present from the Idukki district of Kerala state in India. The sources also analysed the Government of India's women empowerment programs for the empowerment of overall gender development.

\section{Theory for the research - Liberal Feminism}

The 1960s and 1970s had witnessed the beginning of the second wave of feminism, includes the origin of liberal feminism, Marxist feminism, socialist feminism, and developmental feminism. The liberal political approach in the eighteenth century had developed the concept of individual rights by theoretically arguing that differences should not be based on male and female biological or physical appearances, and therefore men and women are not different in society. In the context of this fact, liberal feminists are embracing the idea that women must have equal rights and opportunities in various section, including for higher education. Liberal feminists have increasingly come to view that gender discrimination is most visible in the workplace, especially in terms of disproportionate wage, and also in the decision-making role of government and related institutions. A wide range of inequalities in the political sphere was visible in civil rights, voting rights and the leadership of a movement emphasis the power dilemma between men and women. Hence, liberal feminists claim that women need to be trained in a variety of areas where men are specialised and also promotes the idea that skilled men should come forward to provide such training for women.

Despite the physical difference, liberal feminists advocate the conviction and belief that in terms of confidence and belief, men and women are equal or women are not inferior to men. Liberal feminism promotes the ideology of women's ability to organise, rethink, and implement strategies in the sociological order. The basis of liberal feminism has envisaged by the idea of liberating the oppressive gender of women to the socially equitable society. Women are facing a great deal of discrimination in various sectors of society in western countries as well as developed or developing nations (Tong, 2018). In a society with patriarchal attitudes, it has always been critical for women gender to achieve equality and hence, liberal feminism is empowering women to rise up against such traditional discrimination. They claim that women can achieve equality in society through a variety of legal means and social reforms. It is a matter of great concern that women are often deprived of all kinds of legislative power to promote the socio-economic and cultural upliftment of a country. So that the aim of ensuring gender justice, freedom to interfere in all forms of development of a country, ensuring more women in public policy mechanisms and legislation is a much-needed concern. Liberal feminism proposes the idea that it is the responsibility of any nation to promote gender equality and implement various policies for this aim (Lorber, 1997; Davies \& Gannon, 2011).

Since society is a group of collective individuals, each person must be adequately and unequivocally empowered. In a large country like India with nearly half of its population is comprised of women and girls, it is essential to include women in the development of the country. For that, it is required to include more women in the leadership of political and administrative affairs. It is in such a social context that a policy like the Panchayati Raj is to be implemented in strongly and decisively in India. Due to India's diverse culture and forms of segregation, primarily based on socio-economic and religious differences, the ordinary woman has to face many difficulties and obstacles to attain equality in its society. In this context, the implementation of 50 $\%$ of reserved seats for women in local self-government has increased the chance of attaining equality in the governance level for Indian women. As a result, women can serve society more as a leader by making decisions and exercise all the power and privilege they have as equally as male representatives. Hence, by implementing this policy, the principle of liberal feminism strives to ensure equality for women in the political sphere. Therefore, it is very much advised to carry out the research on the basis of the application of the theory of liberal feminism. By adopting this theory, it is possible to identify the rights of elected women representatives in the governance through the Panchayati Raj system. The concept of equality of liberal feminism process importance in this research since most of the respondents were having less knowledge or experience in the political leadership before and they have tried to achieve their equal status in decision making. 


\section{Methods}

To ascertain the importance of women's political empowerment through the system of PRI, this article focuses on identifying the political empowerment of elected women presidents by considering three main features such as leadership, participation and decision-making capacity in Kerala, which has successfully implemented this PRI policy (Ramakantan, 2009). Kerala is a southern-based Indian state, which population of an estimated population of 35 million, up from 33.38 million as per the 2011 census by Government of India (World Population Review), area occupies $38863 \mathrm{~km}^{2}$ (Government of Kerala). Kerala state comprises 14 districts in total. To achieve the comprehensive analysis Idukki district has chosen. It has a total of 52 LSG (panchayats). There is $50 \%$ of reserved seats for women in the panchayats, in Idukki district total of 25 panchayats are headed by women presidents and thus it was very important to conduct qualitative semi-structured interviews with all these women presidents. Interviews were in the Malayalam language, which is the official language of Kerala. The qualitative interview prompted the respondents to explain the real-life scenario and their opportunities and various impediments in their career as a politician. Through open-ended questions and discussions, it was possible to find out more details about the working scenario. Additionally, the interviewer did observe presidents in their daily job routines and took notes. Basic information about presidents is in Table 1.

Table 1. Characteristics of respondents.

\begin{tabular}{|c|c|}
\hline Characteristics & \\
\hline Age & $\begin{array}{l}20 \text { to } 30-2 \\
31 \text { to } 40-2 \\
41 \text { to } 50-10 \\
51 \text { to } 60-10 \\
61 \text { to } 70-1\end{array}$ \\
\hline Educational qualification & $\begin{array}{l}\text { Up to high school ( } 10 \text { years of schooling })-7 \\
\text { Up to secondary ( } 12 \text { years of schooling })-10 \\
\text { Bachelors ( } 15 \text { years of schooling })-5 \\
\text { Masters ( } 17 \text { years of schooling })-0 \\
\text { Vocational /Professional training ( } 14 \text { years of schooling) }-3\end{array}$ \\
\hline Job experience & $\begin{array}{l}\text { Was employed }-12 \text { (teachers }-5 \text {, social worker }-3 \text {, business }-1 \text {, } \\
\text { agriculture }-3 \text { ) } \\
\text { Un-employed (housewife) }-13\end{array}$ \\
\hline Family & $\begin{array}{l}\text { Married }-24 \\
\text { Un-married }-1 \\
\text { Married with children }-24 \\
\text { Widow }-0\end{array}$ \\
\hline $\begin{array}{l}\text { Participation in Kudumbashree } \\
\text { (SHG) }\end{array}$ & $\begin{array}{l}\text { No experience }-3 \\
1 \text { to } 5 \text { years }-2 \\
6 \text { to } 10 \text { years }-10 \\
\text { Above } 11 \text { years }-10\end{array}$ \\
\hline
\end{tabular}

Source: Author

\section{Women's Political Empowerment}

Grown et al. (2005) identifies the significance of women's political empowerment through the concept of equality. It became intrinsically associated with development in literacy, economic growth, and wellbeing. Nevertheless, women's roles in the political arena have become a vital element of any democratic nation in this millennium; they are constantly being marginalized from the political sphere. Rajput (2001) mentions that the representation of women across all domains, particularly throughout the political process, is fundamental to their progression and the framework 
of gender-equal civilisation. It is imperative to meet the standards of equality, sustainability, and cooperation. The power relationship operates at distinct phases and hierarchies in separate groups, and this hierarchical structure has been evident in the field of empowerment. While females have more possibilities and liberty to engage effectively in political careers in the developed world owing to the profoundly integrated cultural, religious, and social beliefs. In developing countries, they face enormous constraints due to the social, cultural, economic, and patriarchal structure of society. Thus, women's participation in the power structure and their political empowerment is still not adequate to analyse women's position in the political system in developing countries. To improve their involvement at the political stage, it is essential to empower females through multiple programs through the implementation scheme at the local, regional and community levels (Mayoux, 2000).

India's PRI policy is a significant landmark for women's political empowerment due to its features of inclusion of the most substantial women participation in the political sphere. The gender quotas in this policy enable the women to participate in the administrative level decision making in the regional and LSG institutions. Mahatma Gandhi has advocated a system of decentralising the administration in the villages and LSG. This system is known as PRI. The government implemented this advocacy as a legal act by the $73^{\text {rd }}$ Constitutional Amendment Act in 1992. When the elected females become the authority in the village, they were capable of addressing multiple developmental barriers and responsible for making new policies for community development. Kerala is acknowledged for its developmental schemes in comparison with all other Indian states, and thus it is essential to observe how the PRI policy had an impact in the state. The PRI system is a three-tier system. It consists of an elected body (responsible for governance in the district), block panchayat (sub-divisions of district panchayat), municipality, cooperation and in the Grama panchayat (village council) in a state. Table 2 shows the number of elected male and female in the 2015 LSG elections in Kerala.

Table 2. LSG Election 2015 in Kerala elected representatives at a Glance.

\begin{tabular}{|c|c|c|c|c|c|c|c|c|}
\hline Type of LSG & $\begin{array}{c}\text { No. of } \\
\text { LSG }\end{array}$ & Wards & \multicolumn{5}{|c|}{ Elected Members } \\
\cline { 4 - 9 } & & Female & Male & $\begin{array}{c}\text { Schedule } \\
\text { d Cast }\end{array}$ & $\begin{array}{c}\text { Schedule } \\
\text { d } \\
\text { Tribes }\end{array}$ & Gene ral & Total \\
\hline $\begin{array}{c}\text { District } \\
\text { panchayat }\end{array}$ & 14 & 331 & 174 & 157 & 33 & 6 & 292 & 331 \\
\hline $\begin{array}{c}\text { Block } \\
\text { panchayat }\end{array}$ & 152 & 2080 & 1126 & 950 & 219 & 31 & 1826 & 2076 \\
\hline Municipality & 87 & 3078 & 1612 & 1460 & 221 & 16 & 2835 & 3072 \\
\hline Corpora tion & 6 & 414 & 221 & 191 & 26 & 0 & 386 & 412 \\
\hline $\begin{array}{c}\text { Grama } \\
\text { panchayat }\end{array}$ & 941 & 15962 & 8709 & 7226 & 1705 & 243 & 13987 & 15935 \\
\hline Total & 1200 & 21865 & 11842 & 9984 & 2204 & 296 & 19326 & 21826 \\
\hline
\end{tabular}

Source: Local Body Elections Kerala, State Election Commission 2015

The results show that women outnumbered men in all the mentioned institutions. The active involvement of state government for gender equality, higher literacy, awareness campaigns on women's rights, etc. could have an essential role in the altered patriarchal mindset and promotion of more women into politics (Arun, 2017).

\section{Case study}

By the 2011 census, India, the world's second-most populous country, has $48.5 \%$ of its population as females. In the recent election at the national level (lower house of India's bicameral parliament) out of 545 seats, 78 seats were won by women $(14.4 \%)$ which is the highest after Indian 
independence. Whereas the elected men were 462 (85.6\%) (Parliament of India, Lok Sabha, 17 October 2019). Therefore, it is essential to enhance the position of female representation at the national and regional levels. There are numerous factors for marginalising females as a politician in Indian society especially as by tradition, norms, religious affiliation, caste, and household status. Another influential factor for gender inequality in Indian society is the collective nature (Nathawat \& Mathur, 1993) in which individual ambitions sacrificed for the family's fulfilment in the interest of social and cultural acclimatisation. The dynamics of patriarchy continue to dominate the Indian social structure, which becomes the reason for the decline in participation of women in the employment sectors from $37 \%$ (2004-2005) to $29 \%$ (2009-2010) (International Labour Organization (ILO), 13 February 2013). One of the main reasons for women's deprivation and gender inequality is the hegemony that governs culture, regardless of national dimensions (Brysk \& Maskey, 2012). Inequality in the labour market also makes women's life more vulnerable. The majority of firms tend to hire the male over females as women are considered least competitive, or less profitable for the company due to the multiple contingencies including paid maternity leave. Therefore, females are more obliged to the family and authorise males to be the breadwinners in the family. Overall development of the country is stagnated by hindering the financial exercise of women (Razvi \& Roth, 2004; ILO, 2013). There are various hurdles for the woman to be active in the political sphere. They depend on the economy of community, education, social background, work experience, attitude, the cooperation of political parties, family inspiration, and the community in which they live. Fig. 1 shows the number of females, who contested and won in Kerala's legislative assembly general election from 1957-2016. The district of Idukki is one of 14 districts of Kerala with a population of 1108974. It consists of 52 panchayats. Based on PRI $50 \%$ reservation, 25 panchayat presidents in Idukki district are female. To understand the impact of PRI policy on elected female members, it is paramount to recognise the cardinal powers assigned to panchayat leaders. It shows that women's participation in political life has improved over the years concerning the number of females who participated in the electoral system. Nevertheless, the question of great interest persists why Kerala has not made significant progress over the years in accepting more women into a leadership position to the state-level administration.

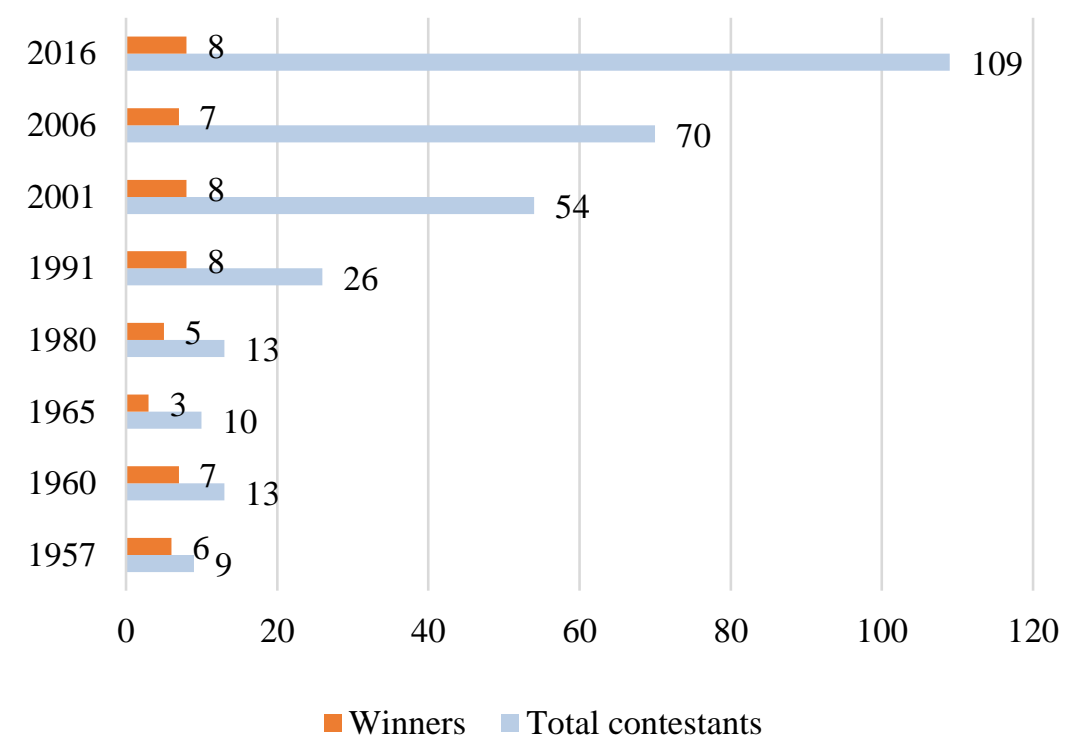

Fig. 1. Number of women, who participated and won in the general elections for legislative assembly in Kerala, from 1957-2016. 


\section{Findings of the study}

Until 2009 there were $33.3 \%$ (Kodoth, 2010) of women's reservation seats in Kerala's LSG but later in 2009, the Government of Kerala increases the women's reservation up to $50 \%$ at LSG and panchayats depending on the 1994 Kerala Panchayati Raj Act (KPRA). Mahatma Gandhi (cited by Jodhka, 2002) considers that the development of a nation like India should start from its village's and hence the implementation of the Panchayati raj mechanism was a significant feature in Gandhi's political vision. He says:

"Independence must begin at the bottom level. Thus, every village should be constituted as a republic or
panchayat, which are having full powers. $<\ldots>$ Therefore, the outermost circumference will not wield
power to crush the inner circle but will give strength to all and derive its strength from it".
(website: https://www.mkgandhi.org )

To reflect on the impact of PRI policy on women's political empowerment, this research would reflect on the key four functions of elected women leaders and assess the involvement in executing those powers. According to the KPRA act of 1994 (p.105-107), there are various powers and duties (provision 156) attached to the elected panchayat presidents/ vice-presidents in the LSG. This study is focusing on the cardinal four powers such as,

1. Preside over and regulate the meetings of panchayat and Grama Sabha of which he [auth. /she] is the president.

Grama Sabha is the grass root level democratic institution in a village in the PRI. In such Grama Sabha discussion, the president plays a significant role throughout organising this communicating with people and addressing numerous economic and social developments in the panchayat. As it does in discussions, panchayat will advocate and enforce respective infrastructure reforms, make the appropriate decisions to sustainable resource allocation to all segments of society without discriminatory practices.

2. Exercise supervision and control over the acts done and actions taken by all officers and employees of panchayat and prepare their confidential reports.

The supervisory position reflects the president's leadership and involvement consistency. One of India's major drawbacks is institutional corruption by politicians and government bodies officials (Widmalm, 2005). It leads to the scenario whereby potential beneficiaries may not benefit from government programs and initiatives. Unless the government lacks accountability, it is hard to distribute different development funds to the right target. Therefore, the president's effective monitoring in a panchayat and its various agencies eliminates any negligence.

3. Incur contingent expenditure up to such limit as may be fixed by the government from time to time.

The role of the president in the distribution of resources would be the decision-making power of the president. For example, the district of Idukki recognised for various natural disasters such as floods and land sliding owing to its geographic structure. The panchayat administration has always been cautious to prevent such destruction. In such a predicament, a president has the privileges and legitimacy to act decisively by helping to make shelter homes, setting up water facility, food, clothes, medicine, etc. in relief camps. In such a crisis phase, it is essential to allocate resources and seek alternative options for all the overall community development. Therefore, the president's decisionmaking power is indeed very vital in the panchayat.

\section{Authorize payment and refunds of the panchayat.}

The position of revenue demonstrates the ability to intervene and negotiate with the government's higher degree of management for more assistance and sanctions for the panchayat. Often, though there is an unsolicited delay in distributing financial means to the institutions upon project completion that results in a panchayat to face economic contingencies, Panchayats is the custodian for obtaining multiple levies and taxes at the regional level, and instances of deficiency of 
revenue could lead to the imbalance in financial management. Therefore, the president needs to be involved in working with the land tax department, revenue authority to avoid further dismissal or halt in fiscal management. To recognize the relevant perspectives of designated female officials in leadership, engagement, and decision-making, it is essential to consider multiple supportive factors. Since most of the respondents were unemployed or resided in a housewife classification and therefore had no opportunity to communicate with a significant number of people, confidence in meetings is an integral part that influences leadership (Fig 2).

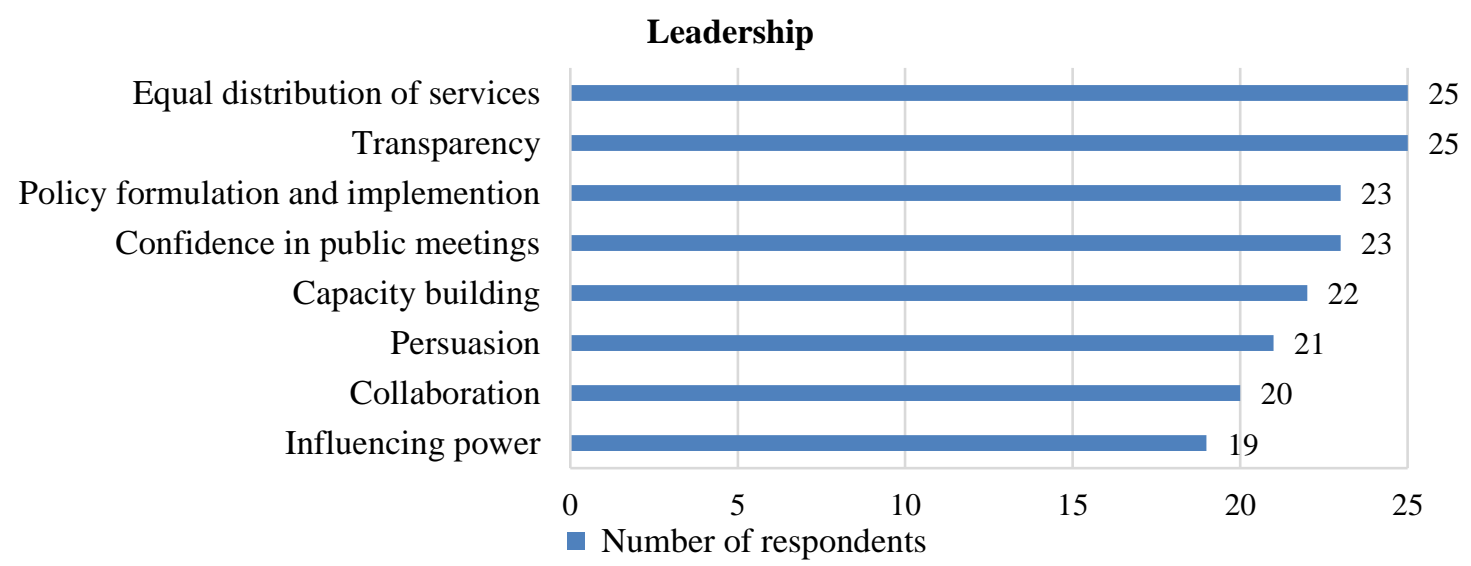

Fig 2. The factors which influence leadership capacity.

Source: Author

Moreover, the power to eradicate illegal practices such as bribery, collaborating with other adjacent panchayats in introducing development projects, a supportive approach to all groups in the region without any bias are critical. To prove that as an efficient leader, they must do things in a timely and responsible manner. Newly elected female leaders had to move from a safe and familiar environment of their home to the public environment; they were expected to do that with confidence and pride. Female leaders faced the necessity to reinvent themselves. Regarding public speech and confidence, as they are required to meet and attend various public affairs as a member. The 45 -yearold person working in Kudumbashree group with high-school level education but no previous experience in politics shared her perception:

\begin{abstract}
"I was a simple housewife until I was selected to be the candidate for the LSG election due to PRI policy, we have $50 \%$ seats in LSG level for women. I was a member of the Kudumbashree organisation, which is a Self-Help Group, for about 20 years and then became the president of that organisation for 4 years. Therefore, people know me, and thus I was able to win in the election. I got the chance to make short speeches at that time, and when I became the panchayat president now, I need to go for many events in a day and requires making public speeches. So, from a simple house to the president, I have got the confidence to have a public discussion or for speeches or be the moderator in various meetings".
\end{abstract}

(Anonymous 1, 2019)

When elected as members, they should participate with separate groups of society. A representative seems to have no precise work hours. This is a superior challenge for female leaders, particularly in terms of mobility conditions interactions to male coworkers, negotiation with political stakeholders. The leader (41 years old) with a Bachelor level education and no prior experience in politics or Kudumbashree group voiced the importance of capacity-building, compassion, and increasing the quality of life of society:

"During the 2018 flooding in Kerala (The New Indian Express), our panchayat was very much affected by land sliding. To prevent the loss of people's lives, as the president, I was required to have extensive travelling in the night to coordinate the rescue mission. For about over a month, I was not able to be back at my home by evening but only by midnight. This kind of situation had later created internal conflict in 
my family life. Later my entire family was supporting what I am doing. So that I can do my best for the panchayats overall development".

(Anonymous 2, 2019)

In the Idukki district, a big part of economic revenue consists of tourism. Hence there many commercial trading occurs. In such cases, development projects that do not harm the environment have priority. On the contrary, the panchayat had to deny the permit for large-scale projects by corporate companies (building resorts, business establishment) that would have had a significant negative impact on the environment and society. That led to bribery or even coercion. In such circumstances, the leader must remain consistent with the policy and regulations. The active leader of Kudumbashree group (54 years old) who holds just a high-school certificate, nevertheless has this position for over 12 years considers that transparency is an essential factor for good governance. She added that:

"I am coming from an affluent political family where my father was a well-known politician. So that I
was aware of the fact that to be successful in my political career, I have to be very diplomatic to every
person in my society. There were various situations where I denied sanction building construction because
I had to follow the rule by the government in terms of preventing building constructions especially like
resorts in the ecological conservation areas. Opposite party members were forcing me to sanction such
projects for their vested interests, but as a leader who was elected by my people, I will not do anything
harmful or make any wrong policies".

(Anonymous 3, 2019)

In consideration of the participation (Fig 3) in the panchayat governance, it is essential to identify the leader's ability in assessing the needs and requirements of panchayat such as constructing a road, building hospitals, providing assistance for schools especially in the tribal areas where much more attention is required. The elected representatives are fully responsible for all forms of development in their administrative centres. The top leader of panchayat has the power to implement the state-level development projects properly in his/her panchayat. The leader needs to work closely with the various departments and local parties in the area for the implementation of such exact systems. Therefore, it is the responsibility of an excellent leader to bring everyone together and work for the overall development of panchayat. There is a need to bring together various social NGOs and religious organisations for the development of panchayat. As an illustration, 54 years old respondent with a high school education and almost 14 years of membership in a political party declared:

"As a woman president I was able to properly coordinate the LSG process and which enables me to assess the policies and programs under my jurisdiction and to properly report and inform to the higher authorities and to facilitate for further enhancement and financial assistance in my panchayat".

(Anonymous 4, 2019)

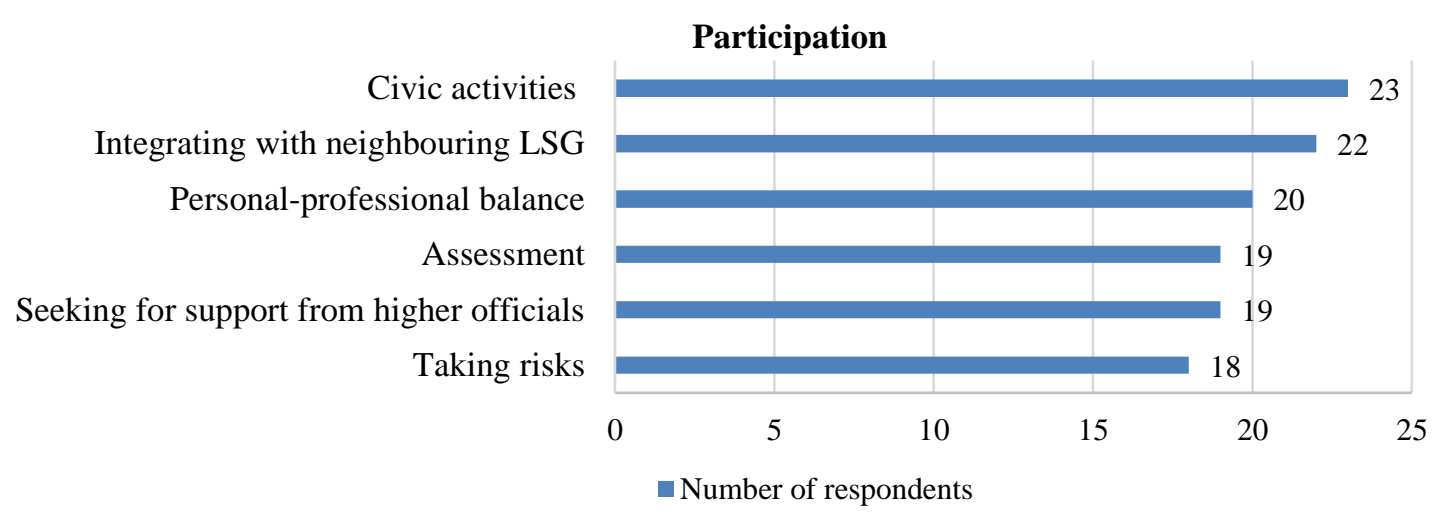

Fig 3. The factors which influence civic participation. 
Almost all respondents admitted that to succeed as a female politician and participate in the welfare process, they require much support from their family, specifically from the husband and his family along with kids is a significant part. They had to be willing to take risks, actively participate in all social causes. In those cases, as women, presidents had to face abusive and disrespectful emotional, physical, or verbal harassment. While discussing the consequences of finding a balance between personal and professional life as a women politicians 44-year-old respondent with secondary education and active membership in Kudumbashree group and political party for over 10 years emphasised:

\begin{abstract}
"Once I had to face a huge verbal abuse from a businessman, who visited the panchayat for allowing him to start the land mining operations in his property because that area was surrounded by many inhabitants and could lead to drought in future, I had to decline his request. Therefore, he started abusing me, and I was very sad. Despite criticism, my administrative staff, other members of my party and the opposite party stood with me, and we will stand together for justice. When I reached home, my family was also supporting me for the decision".
\end{abstract}

(Anonymous 5, 2019)

Therefore, the respondents agreed that if they do not have any support from family, especially from their partner, it is very hard for women to continue their political careers. Thus, from the primary level interactions, it perceived that the women leaders consider the aspect of participation as a significant factor to be a successful politician. In certain instances, the leader must collaborate with local party officials on various policy implementation. Women often are considered to be weaker gender, that is why culturally it is harder for women to impose their opinion, they do face a lack of respect not just from the chiefs or colleagues, but subordinates as well. Women have to overcome such issues to implement their policies and organise management of panchayat fluently. Thus, a proper policy framework without any delay or disagreement from the opposing party is essential for panchayat's governance. When addressing the ability to make the agenda for the future actions, another participant who is 54 years and having secondary education with an experience of participating in political activities for over 15 years and in Kudumbashree group for over 10 years added:

"As the women president in my panchayat, I believe that I was able to properly manage to coordinate other board members to set priorities for the next year's development plan, and hence we were able to discuss further on necessary projects which need quick implementation. In most cases, such decisions are required while dealing with funding allocation. Sometimes, some members would like to have more money in their ward, but ultimately a core committee decides to distribute funds. Thus, we always make sure that every ward gets equal justice and consideration".

(Anonymous 6, 2019)

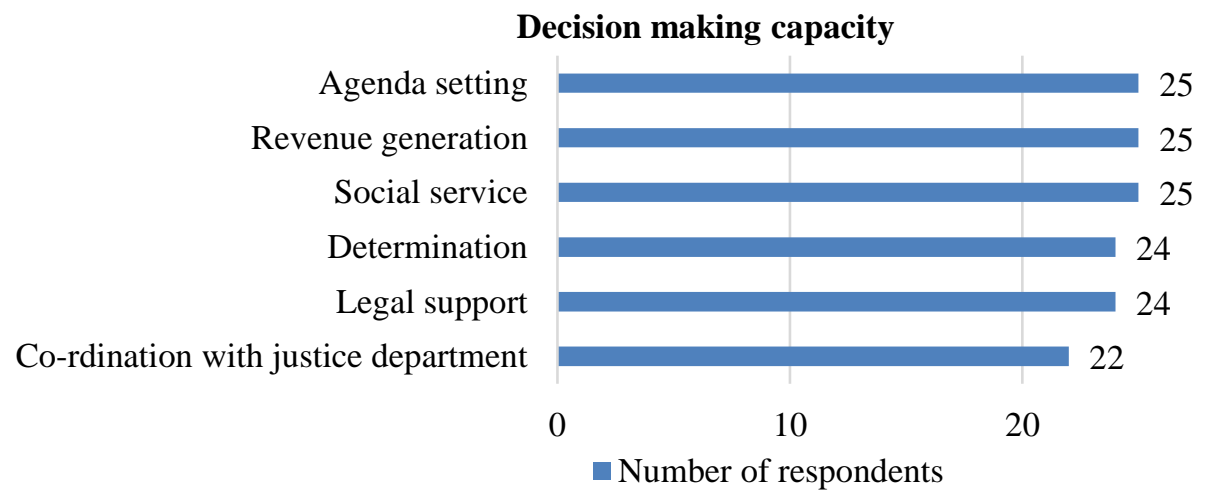

Fig. 4. The factors which influence decision-making capacity. 
It is the great responsibility of any panchayat president to foster children's development, poverty reduction, and prevention of violence against women, protection of vulnerable or, if essential, seek assistance from police, fire department, NGOs, and women's commissions in that region. About self-determination and social service strategy, another respondent (51 years old) with just high school education yet with an extensive experience of participating in political activities for over 8 years claimed:

\begin{abstract}
"I believe that to ensure all these things, the greatest factor is the aspect of self-determination, which I gathered through participation in the political process and the activities of Kudumbashree group. Working as the member in the beginning stage and then later on becoming the president of our Kudumbashree for more than 2 years gave various opportunity in my life like meeting the important politicians, being a member in development discussions, interacting with higher officials etc., which imparts me the necessary skills which enabled my self-confidence and self-determination".
\end{abstract}

(Anonymous 7, 2019)

In addition to offering relevant legal support to senior citizens, or aiding orphan or accompanying victims of domestic abuse, as panchayat president, they always had to be accessible for duty. One participant who is 41 years and has secondary education with 11 years of experience in politics shared:

\begin{abstract}
"I always wanted to be a social worker, and once my society realised me as a leader, they started to promote me to be a contestant in the general election. I am very sure that, if our government did not try to implement the PRI policy for women's equality and more access for women to be in politics, I would not be able to be the leader of my people. I will be like a normal traditional family woman who ends up her days and night by cooking and cleaning, taking care of kids and husband, and will never be the person now. Thus, I accept and will do my best for the people who elected me in this position. I will never break that trust".
\end{abstract}

(Anonymous 8, 2019)

Furthermore, through primary level observations, it can be identified that women in politics recognise their decision-making role as more of the pivotal importance of women empowerment to be competent leaders in the community.

\title{
Conclusions
}

In India, over decades, is the central government had implemented policies for society's sustainable progress. Nevertheless, women often denied significant political empowerment. The implementation of PRI in 1992 initiated women's political empowerment at the national and regional levels. The dynamics of this strategy have generated further opportunities for women to be regional decision-makers and thus have more equality in all areas of society. Since liberal feminism promotes the idea of equality by empowering individuals, the PRI policy is having a significant role in women's political empowerment. In the state of Kerala, this policy made considerable progress in supporting many females throughout the LSG decision making. The analysis reveals that women can participate and take decisions equally throughout the political process as a representative and that they are not be secluded based on gender. The empirical study highlights that appointed women perceive their position and power as an effective tool for transforming progress and development in their panchayat despite corruption and discrimination. They also point out multiple challenges and hindrances to maintaining a political career without any exclusion. The implementation of PRI in the district of Idukki enables several women to be an active leader in the social and political area than ever before.

\section{References}

1. Anonymous 1. Interview/ Interviewer: T. Varghese. Idukki, India, Approximately 3 hours, Malayalam (accessed March 03, 2019). 
2. Anonymous 2. Interview/ Interviewer: T. Varghese. Idukki, India, Approximately 2 hours, Malayalam (accessed March 06, 2019).

3. Anonymous 3. Interview/ Interviewer: T. Varghese. Idukki, India, Approximately 2 hours, Malayalam (accessed March 09, 2019).

4. Anonymous 4. Interview/ Interviewer: T. Varghese. Idukki, India, Approximately 1 hour, Malayalam (accessed March 23, 2019).

5. Anonymous 5. Interview/ Interviewer: T. Varghese. Idukki, India, Approximately 2 hours, Malayalam (accessed April 10, 2019).

6. Anonymous 6. Interview/ Interviewer: T. Varghese. Idukki, India, Approximately 2 hours, Malayalam (accessed April 15, 2019).

7. Anonymous 7. Interview/ Interviewer: T. Varghese. Idukki, India, Approximately 3 hours, Malayalam (accessed April 18, 2019).

8. Anonymous 8. Interview/ Interviewer: T. Varghese. Idukki, India, Approximately 1 hour, Malayalam (accessed April 20, 2019).

9. Arun, Shoba. Development and gender capital in India: Change, continuity and conflict in Kerala. Routledge, 2017.

10. Batra, Renu, and Thomas G. Reio Jr. "Gender inequality issues in India." Advances in Developing Human Resources 18, no. 1 (2016): 88-101.

11. Berkovitch, Nitza, and Adriana Kemp. "10 Economic empowerment of women as a global project." Confronting Global Gender Justice (2010): 158.

12. Brysk, Alison, and Aditee Maskey. "Rethinking trafficking: Patriarchy, poverty, and private wrongs in India." Global Dialogue (Online) 14, no. 2 (2012): 42.

13. Davies, B., and S. Gannon. "Feminism/Post-Structuralism in Stomekh, B. and Lewin, C." Theory and Methods in Social Research 2 (2011): 312-320.

14. Gandhi, Mahatma, and Ramachandra Krishna Prabhu. Panchayat raj. Navajivan Publishing House, 1959.

15. Gandhiji and Empowerment of Women. Panchayati Raj. https://www.mkgandhi.org/ articles/womenempowerment.htm. (accessed October 17, 2019.

16. Government of India. Women and Men in India. 2019. A statistical compilation of Gender related Indicators in India. Ministry of Statistics and Programme Implementation, New Delhi.

17. Government of Kerala. About Kerala. Retrieved from https://kerala.gov.in/about-kerala. (accessed October 15, 2019).

18. Government of Kerala. Idukki, Panchayats. Retrieved from https://idukki.nic.in/ departments/panchayat/ (accessed October 15, 2019).

19. Grown, Caren, Geeta Rao Gupta, Aslihan Kes, and Projet Objectifs du millénaire. Taking action: achieving gender equality and empowering women. London: Earthscan, 2005.

20. International Labour Organization. (2013). ILO'S global report. Retrieved from http://www.ilo.org/wcmsp5/groups/public/—dgreports/—dcomm/—publ/documents/publication/ wcms_202326.pdf

21. International Labour Organization. Gender gap. India: Why is women's labor force participation dropping? Retrieved from https://www.ilo.org/global/about-the-ilo/newsroom/commentanalysis/WCMS_204762/lang--en/index.htm (accessed February 13, 2013).

22. Johnson, Susan. "Gender relations, empowerment and microcredit: moving on from a lost decade." The European Journal of Development Research 17, no. 2 (2005): 224-248.

23. Kark, Ronit, Boas Shamir, and Gilad Chen. "The two faces of transformational leadership: Empowerment and dependency." Journal of applied psychology 88, no. 2 (2003): 246.

24. Kodoth, Praveena. "Globalisation and Higher Education in Kerala: Access, Equity And Quality." Report submitted to the Sir Ratan Tata Trust. Retrieved from: http://srtt. org/institutional_grants/pdf/globalis a tion_higher_education.pdf (2010).

25. Lorber, Judith. The variety of feminisms and their contributions to gender equality. Bis, 1997. 
26. Parliament of India. Lok Sabha. Gender-wise Representation of Members. Retrieved from http://loksabhaph.nic.in/Members/ GenderWiseStatisticalList.aspx (accessed October 17, 2019).

27. Mahatma Gandhi. Panchayat Raj. Retrieved from https://www.mkgandhi.org/ momgandhi/chap78.htm (accessed October 10, 2019).

28. Mayoux, Linda. Micro-finance and the Empowerment of Women: A Review of the Key Issues. No. 993441343402676. International Labour Organization, 2000.

29. Narayan-Parker, Deepa, ed. Measuring empowerment: cross-disciplinary perspectives. World Bank Publications, 2005.

30. Nathawat, S. S., and Asha Mathur. "Marital adjustment and subjective well-being in Indianeducated housewives and working women." The Journal of psychology 127, no. 3 (1993): 353358.

31. Pratchett, Lawrence, Catherine Durose, Vivien Lowndes, Graham Smith, Gerry Stoker, and Corinne Wales. "Empowering communities to influence local decision making: systematic review of the evidence." (2009).

32. Rajput, P. "Women's political participation in India: An agenda for empowerment." Empowering the Indian Women, New Delhi, Ministry of Information and Broadcasting, Government of India 2 (2001).

33. Ramakantan, N. "Democratic decentralization and empowerment of local government associations in Kerala." Commonwealth Journal of Local Governance (2009): 128-136.

34. Razvi, Meena, and Gene L. Roth. "Women's Socio-Economic Development in India: The Role of Non-Governmental Organizations." Online Submission (2004).

35. State Election Commission. Local Body Elections Kerala 2015. Retrieved from http://lsgelection.kerala.gov.in/lbtrend2015/views/index.php (accessed August 21, 2019).

36. The New Indian Express. Kerala floods:Idukki struggles with relief efforts as death toll climbs to 51. Retrieved from http://www.newindianexpress. com/states/kerala/2018/aug/20/keloods-idukkistruggles-with-relief-efforts-as-death-toll-climbs-to-51-1860292.html (accessed August 20, 2019).

37. Tong, Rosemarie. Feminist Thought, Student Economy Edition: A More Comprehensive Introduction. Routledge, 2018.

38. Widmalm, Sten. "Explaining corruption at the village and individual level in India: Findings from a study of the Panchayati Raj reforms." Asian Survey 45, no. 5 (2005): 756-776.

39. World Population Review. Kerala Population primarily 2019. Retrieved from http://worldpopulationreview.com/territories/kerala-population/ (accessed October 17, 2019).

Titty Varghese

\title{
Moterų politinio įgalinimo politikos poveikis: Indijos Keralos valstijos Idukki rajono atvejis
}

\author{
Anotacija
}

Per paskutiniuosius dešimtmečius ženkliai išaugo moteru politinè galia ir moterų vaidmuo politiniuose procesuose. Tačiau moterų įtaka vis dar nėra proporcinga vyrų daromam poveikiui. Tai ypač pastebima teisèkūros ir teisinių praktikų diegime ir reprezentacijoje. Todèl yra svarbu organizuoti moteru politinio igalinimo tyrimus bei mokslinius debatus apie moters vaidmeni ir reprezentaciją politinejje arenoje. $1992 \mathrm{~m}$. Indijos vyriausybè prièmé Nacionalinę programą „Panchayati Raj Institutions“. Ši programa yra puikus politinio mechanizmo, didinančio moteru dalyvavimą politiniuose procesuose, pavyzdys. Šiuo ịstatymu moterims yra suteikiama $50 \%$ vadovaujančių vietų vietos savivaldos institucijose. Tokiu būdu moterys bent jau oficialiai ịgijo lygias teises vietos savivaldoje. Ši programa taip pat prisideda prie moterų didesnio matomumo politinèje 
arenoje, todèl moterys turi daugiau galimybių būti išrinktos ị politinius postus ir tokiu būdu atlikti svarbesnị vaidmenį sprendimų prièmimo procesuose. Atsižvelgiant į esamą kontekstą, šiuo tyrimu yra siekiama išnagrinèti vietos savivaldos institucijų itaką igalinant moteris siekti svaresnio politinio vaidmens ir reprezentacijos. Tam buvo pasirinktas empirinis tyrimas. Jị sudare kokybiniai interviu su vietos savivaldos politiniais lyderiais Indukki rajone Keralos valstijoje Indijoje. Pirminių duomenų analizė atskleidė moterų politinės galios augimą ir šio augimo reikšmę Keralos valstijoje.

Titty Varghese - a doctoral student at the Faculty of Social Sciences, Arts, and Humanities, Kaunas University of Technology.

email.: titty.varghese@ktu.edu

Titty Varghese - Kauno technologijos universiteto, Socialinių, humanitarinių mokslų ir menų fakulteto, socialinių mokslų daktorantè.

email: titty.varghese@ktu.edu 